\title{
A study of development and changes of coastal settlements taking Hongmao Harbour as an example
}

\author{
S.-C. Lin
}

Department of Architectural Engineering, Kao Yuan University, Taiwan

Architect, Southeast University, Nanjing, People's Republic of China

\begin{abstract}
Settlements originate from the inhabitancy of people in a region. The formation of its spatial form is caused by the natural conditions of the environment where the people are situated, and results from the mutual influence among the factors of community relationship, cultural concepts, construction technology, and so on of the inhabiting people. Settlement always varies with the change of these factors in their development process. This paper studies the case of a settlement in the form of a fishing village in Hongmao Harbour, which is located at the western side of Kaohsiung City with a history of development of over three centuries, and is formed by several single-last-name villages. By collecting the historical information, comparing the ancient maps with the current situation, and referring the ownership of land with the kinship, this paper clarifies the development and change of the settlements in Hongmao Harbour through the 100 years and more since the end of the Ching Dynasty, and analyzes the main factors affecting the formation of the existing style and features of the settlements, including the erosion of sea tides, cultural concepts, pressure of population growth, community relationship and land inheritance system. Moreover, through the distribution of ethnic groups in each single-last-name village and the overlapping of worshipping circles of temples, the paper induces the characteristics of the worshipping circles of Hongmao Harbour that takes kinship as the main axis.
\end{abstract}

Keywords: settlements, single-last-name village, worship circle. 


\section{Introduction and research approach}

Settlements originate from the inhabitancy of people in a region. The formation of its spatial form is caused by the natural conditions of the environment where the people are situated, and results from the mutual influence among the factors of community relationship, cultural concepts, construction technology, and so on of the inhabiting people. Settlement always varies with the change of these factors in their development process. This paper studies the case of a settlement in the form of a fishing village in Hongmao Harbour, which is located at the western side of Kaohsiung City with a history of development of over three centuries, and is formed by several single-last-name villages. By collecting the historical information, comparing the ancient maps with the current situation, and referring the ownership of land with the kinship, this paper clarifies the development and change of the settlements in Hongmao Harbour through the 100 years and more since the end of the Ching Dynasty, and analyzes the main factors affecting the formation of the existing style and features of the settlements, including the erosion of sea tides, cultural concepts, pressure of population growth, community relationship and land inheritance system. Moreover, through the distribution of ethnic groups in each single-last-name village and the overlapping of worshipping circles of temples, the paper induces the characteristics of the worshipping circles of Hongmao Harbour that takes kinship as the main axis.

Regarding the research approach, this paper makes a synthetic collation and cross-comparison of the substantive historical materials, verbal historical materials and archives-based historical materials, clarifies the development procedures of the settlements, and then analyzes the factors affecting the development. For the substantive historical materials, a general survey is adopted to investigate, measure and draw the space of the settlements. For the oral historical materials, interviews with old people are arranged so as to clarify the development and change of the settlements. For the archives-based historical materials, the major source of information includes local history, maps, old photographs, cadastral information, household information, and so on. Among them, the local history includes History of Fengshan County, History of Taiwan Prefecture, Revised History of Kaohsiung City, etc. The maps include 3 sea maps drawn by the Dutch of the $17^{\text {th }}$ century in 1636, 1664, and 1682-1733 respectively, official maps of different dynasties published by the Great Empire of Ching Dynasty in the $18^{\text {th }}$ century and the $19^{\text {th }}$ century, the topographic maps drawn by the Japanese government in 1903 and1928, and the maps, urban planning pictures, orthophotos and digital orthoimage maps published by the government of the Republic of China ever since it took over Taiwan in the 1945 until now. Among them, the topographic maps drawn in 1903 provide the coastline of Hongmao Harbour and a complete record of cadastral numbers of that time, being one of the important references for re-establishing the form and features of Hongmao Harbour in the early $20^{\text {th }}$ century. The cadastral information is mainly the cadastral maps of Hongmao Harbour drawn from the Japanese colonization period until today, which are collected by Cianjhen Land 
Administration Affairs Office of Kaohsiung. The ownership of buildings is based on the List of Hongmao Harbour Residents Receiving Compensation provided by Kaohsiung Harbour Bureau. The information is helpful to reconstruct the distribution of ethnic groups of settlements.

\section{Geographical environment and its changes}

Hongmao Harbour is located at Haishan in the southeastern part of Takao (Cihou), with its southern side connecting with Dalinpu and Fengbitou, northern side separated by the waterway of the Second Kaohsiung Port and JhongJhou, and facing Cijin. Its eastern and western sides reach the water margins: its eastern side is Takao lagoon (today's Kaohsiung Harbour) commonly called "Inner Sea," and its southwestern side is Taiwan Strait, commonly called "Outer Sea." The area covered is at the width of 300 and more meters and at the length of about 3,000 meters. If it includes Putouzai, the length can reach 3,927 meters (Figure 1).

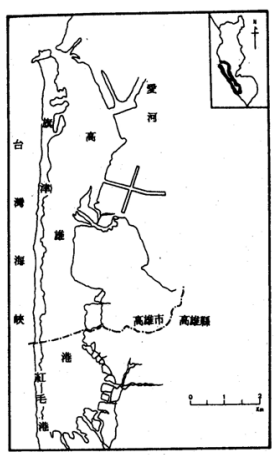

Figure 3: Site map of Hongmao Harbour in 1979.

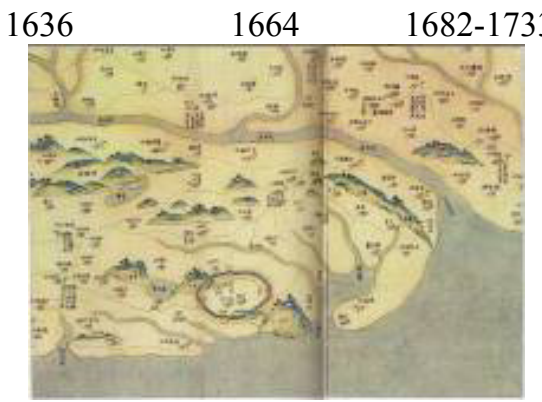

Cianlong Illustrated Taiwan Maps drawn from 1756 to 1759
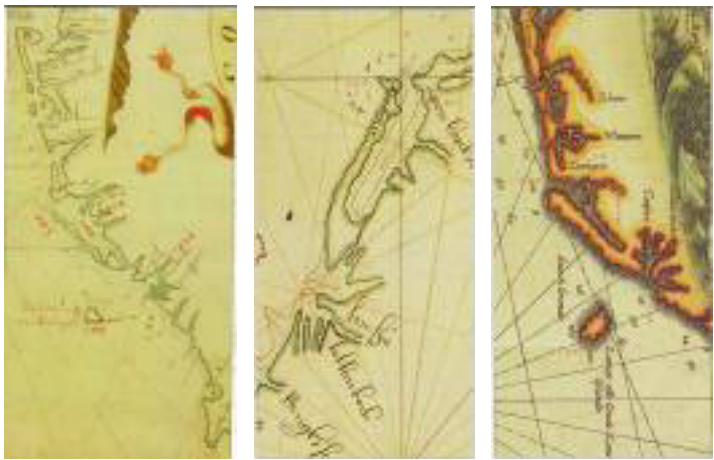

Figure 4: Ancient maps during the Dutch colonization period.

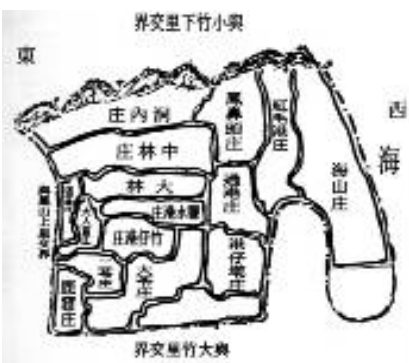

Site map of Hongmao Harbour Village, Haishan Village in the 1890s

Figure 3: Ancient maps during the Manchurian occupation period. 


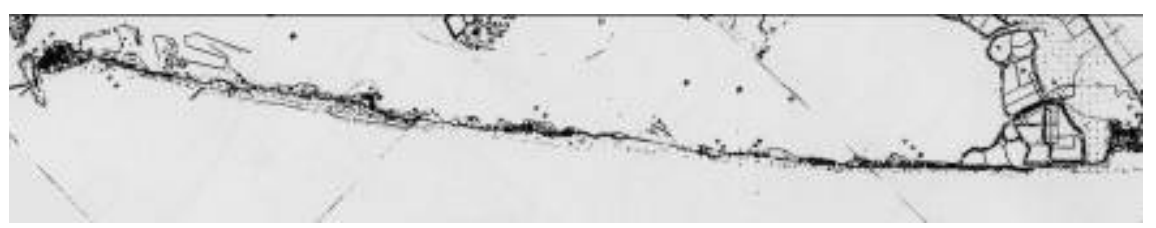

Figure 4: Map during the Japanese colonization period.

As observed from the ancient maps, the current form and features of Hongmao Harbour are extremely different from the past. The paper takes the existing ancient maps that describe the earliest form and features of Hongmao Harbour during the Dutch colonization period, for example. On the three ancient maps drawn in 1636, 1664 and 1682-1733, Haishan where Hongmao Harbour was located, appears clearly, and is indicated by the word, "port" (Figure 2). After these three maps and the ancient maps (Figure 3, Figure 4) subsequently drawn during the Manchurian occupation period and the Japanese colonization period are compared with the form and features of Hongmao Harbour (Figure 5), it is found that its four sides have been obviously different, indicating the change of geographical environment of Hongmao Harbour.

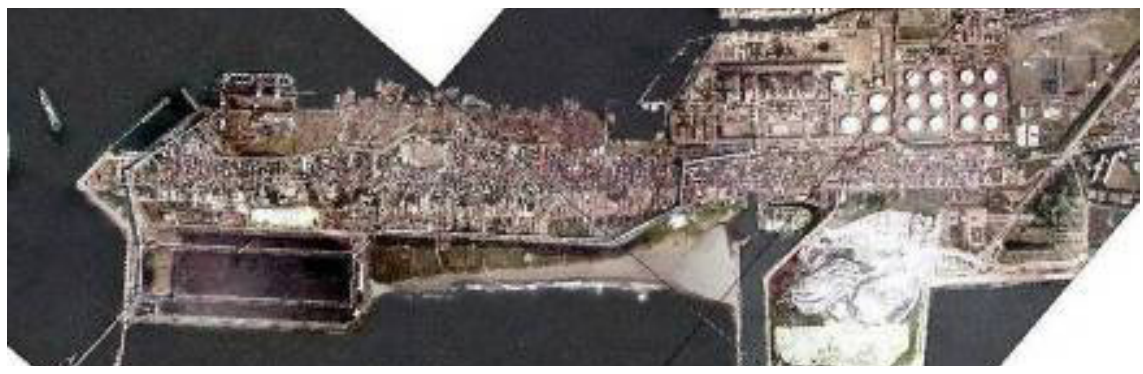

Figure 5: Current map of Hongmao Harbour.

One thing is that on the ancient maps, Haishan where Hongmao Harbour was located in the early days is connected with the part of Haishan where today's Jhongjhou and Cijin are located; but the current situation is that they are separated by the water course of port. The main reason for the separation was that in 1968, Kaohsiung Harbour Bureau opened the second port at the "gap" at the northern end of Hongmao Harbour, so as to alleviate the growing handling capacity of containers at Kaohsiung Harbour. From then on, Haishan where Hongmao Harbour was located was separated from the northern end of Haishan where Jhongjhou and Cijin are located.

The second thing is that on the ancient maps, the width from the east to the west of Haishan where Hongmao Harbour was located is obviously from that of today. On the maps the width from the east to the west is only 100 meters, whereas today the width is as wide as 300 meters. The main reason behind is the land reclamation for creation of new land. As shown from the ancient maps, ever since the early $20^{\text {th }}$ century, the act of land reclamation for creation of new 
land appeared in Hongmao Harbour. According to the different times and the different ways of land reclamation, land reclamation was divided into two stages, land reclamation by labour and land reclamation by mechanical power. Originated from the early $20^{\text {th }}$ century, land reclamation by labour sustains until the 1960's. At the shallow beach of Takao Bay in the eastern side of Haishan, people used the coral reef rocks (commonly called "laogu rocks") produced in the neighbouring areas to build a rectangular embankment. Inside the embankment was filled with the sea sanddug from the outer sea. The right of land reclamation belonged to the residents living in the western side of the coastline. In the very beginning, the right of land reclamation belonged to the residents of courtyard houses closest to the coastline. After the project of land creation was completed, the right of land reclamation was transferred to the owners of courtyard houses behind those being closest to the coastline. Such transfer went on and on in cycles. The right of land reclamation transferred with the transfer of the ownership of land of the inner settlements of coastline. In terms of dimension, the width of reclaimable land was equivalent to the width of the original land ownership, but the depth was discussed and further confirmed by the elders of families or the fair celebrities of the settlements. Since land reclamation by labour belonged to the behaviours of individuals done by labour and the area of land reclamation had to comply with the public commitment of the settlements, spontaneous land reclamation and creation of new land done by the civilians could only acquire land of limited area. As found on the maps in the early $20^{\text {th }}$ century, the depths of the neighbouring pieces of land are different. There appears the scene that lots of road in the eastern side protruded towards the inner sea (Figure 6). As observed from the order of numbers of the cadastral maps of land, the land reclamation by labour with hardships gradually stretched towards the inner sea. The land reclamation by mechanical power did not appear until 1968. In order to construct Dalin Thermal Plant, develop the Second Port and reclaim Kaohsiung Harbour, a great volume of sea sand was extracted and piled up in "Putouzai" at the front end of Hongmao Harbour and the coast by the eastern and western sides. Since these were the public construction projects implemented by the government, they were done by mechanical power. Because of this, the area of land became broadened. Within a short period of time, the width from the east to the west of Haishan where Hongmao Harbour was located had been immensely expanded.

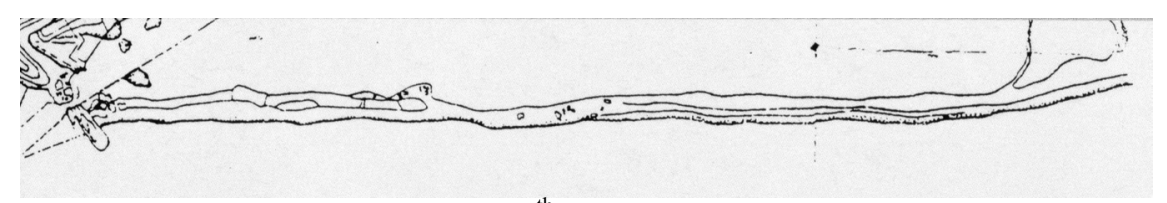

Map of Haishan in the $8^{\text {th }}$ year of Taishou Reign (1919)

Figure 6: Hongmao Harbour shown on the map drawn in the early 20th century. 
The third thing is that the form and features of "Putouzai" at the junction of Hongmao Harbour and Dalinpu at the southern end are extremely different between the past and the present. The ancient maps show that the original location of "Putouzai" was at the shallow beach of Takao Bay. In the early days the local citizens encircled the sea zones by building weirs and embankments. The encircled zones here became fish ponds and salt fields. These records can be found on the ancient maps and the related archives-based historical materials. Later on, in 1963, this area was incorporated to Linhai Industrial District. With the successive establishment of the Steel Refinery and Thermal Plant, "Putouzai" gradually changes its original topography and morphology in the process of land reclamation and creation of new land.

The fourth thing is that there are changes always found at the positions of eastern coastline on the ancient maps. It was mainly caused by the monsoon wind as well as the change of sea tide at the western side and of sea current close to the coast. Due to the effects of monsoon wind, as well as the sand at the southern side flowing westward from the east and alleviating at the river mouth of Danshuei River (today's Gaoping River), a lot of changes were caused to the coast. Therefore, in winter and spring the beach line is longer and the sea surface is so peaceful that ship can anchor here. Nevertheless, in summer and autumn, the wind direction is changed. The beachhead is always eroded, and the beach line is close to the coastline. In addition, there are attacks of typhoon. Sea waves even rush to the coastline, cross over Haishan and flow to the inner sea. This phenomenon not only makes the western coast of Hongmao Harbour become an unstable region, the great waves in summer and autumn and the sea water erosion along the coast also seriously affect the utilization of land. On the cadastral maps of Hongmao Harbour drawn in the early days, the land of the western coast is always found to have the construction land originally indicated as "construction," but corrected as "field". "Field" refers to the waste land not being used or reclaimed. The land along the western coast was enormously changed from construction land to be waste and abandoned land. It implied to the unstable situation of the land along the western coast. This phenomenon was not improved until the completion of the successive construction of embankments in 1953.

\section{Development of settlement and spatial characteristics}

According to the historical materials, as early as the Dutch colonization period, there were fishermen inhabiting here and earning their livelihood by fishing. At that time the Chinese people called the Dutch "Hongmaofan," meaning redhaired foreigner, so the name of this place was called "Hongmao Harbour." During the Tseng Cheng-kung period in Ming Dynasty, Hongmao Harbour was the settlements belonging to Wannian County. It contained the typical settlements in the form of Chinese fishing villages. The migration of the Chinese to Hongmao Harbour started from this time. During the Manchurian occupation period, Hongmao Harbour was under the jurisdiction of Fengshan County. The industry of the settlements was still mainly fishing. During the 
early Japanese colonization period, Hongmao Harbour was renamed as "Hongmao Harbour Village," subordinating to Fengshan Lower Village of Tainan Government Office. In 1920, it was change to be under the jurisdiction of Kaohsiung State, and the settlements were divided into five divisions. After the Second World War, Hongmao Harbour was subordinated to Kaohsiung County. In 1947 the five divisions of Hongmao Harbour Village divided during the Japanese colonization period were changed to be five villages, which were named as Haiceng, Haichang, Haifeng, Haiyuan and Haicheng. On the $1^{\text {st }}$ day of July in 1979 Kaohsiung City was upgraded as a city under the jurisdiction of the Central government. Accordingly, Siaogang Village was incorporated in Kaohsiung City, and the administration division of Hongmao Harbour area was changed to be five neighbourhoods, being Haiceng, Haichang, Haifeng, Haiyuan and Haicheng.

In 1968 Hongmao Harbour was incorporated in the area of Linhai Industrial District, and no further construction was allowed. From then on, the style and features of settlements were consolidated. Today the lines of settlements and the form of buildings are generally retaining their old look, without any great changes. Following the sequence of the route system, route direction, districts and nodes, the paper describes the spatial characteristics of the settlements.

\subsection{Route system}

Regarding the route system, the arrangement of the roads of Hongmao Harbour looks like the fish bone. Haishan Road in northwest-southeast direction is the skeleton of space, with narrow lanes and small roads extending to the eastern and western sides. The winding Haishan Road is 3 and more kilometres long. Its southern end links to Dalinpu, and its northern end is facing Gaozi tower and connecting with the Second Port. Its width is between 4 and 6 meters. The lanes by the eastern and western sides are narrower than Haishan Road. These lanes are arranged to have a wide lane followed by a narrow lane, and so and so forth. The wider lane is about 6 chihs (1.8 meters) wide, and the narrower lane is mostly less than 3 chihs (0.9 meters). Some lanes are even less than 2 chihs $(0.6$ meters) wide, only available for passing through by one person on his/her side. The lanes in the eastern side of Haishan Road are longer, but those in the western side are shorter. According to the local elder people, the distribution of settlements is mainly concentrated in the eastern side of Haishan Road. Originally, Haishan Road was the western marginal harbour coast of the settlements. Later on, due to the gradual deposition of coastline, land reclamation and creation of new land, the area of settlement gradually extended to the western side of Haishan Road.

On the cadastral maps drawn during the Japanese colonization period and the overlapped maps of today's urban planning pictures, besides the indication of the road at the position of Haishan Road, there are several road sections appeared in the western side of today's Haishan Road, and some branch roads linked to the old Haishan Road. Among them, Putouzai is the longest one. It turns to the west on the old Haishan Road at the place of cadastral No. 27-3. It is almost parallel to the old Haishan Road. It extends northwestwards to the place of today's 
cadastral No. 67, and turn east to connect with the old Haishan Road. For the part of the branch road, construction land is also found distributed in the western side in the early days. It should be a passage way for the citizens living in the western side of the old Haishan Road and close to the outer sea. Today the branch road is not found anymore. The reason for its disappearance is related to the migration of the outer sea citizens to the inner sea area for evasion of sea tide attack, as well as the loss of the road's function with the gradual abandonment of construction land.

Besides, on the abovementioned cadastral maps, at the area between cadastral No. 108 124, No. 187 219, and No. 224 230, there are branch roads connecting with the old Haishan Road. Their functions and the reasons for their disappearance should be the same as the above. There is one thing worth mentioning that all these branch roads appear at the juncture of settlements of different last names, instead of appearing in the central part of the settlements of the same last name. Among them, cadastral No. 108 was at the juncture of "Yang's Family" and "Wu's Family," cadastral No. 187 was at the juncture of "Li's Family" and "Hong's Family," and cadastral No. 224 was at the juncture of "Su's Family" and the family of other last name. Even in front of the settlement of "Jhang's Family," where the Second Port was located, is constructed with branched roads. It explains that the settlements of different last names in the early days had the construction land close to the outer sea constructed with the horizontal linking roads in front of their settlement. The appearance of the subsections of these horizontally linking roads and the linkage between the margin of settlements and the old Haishan Road explain that the branch roads inside the settlements of a single last name are for the purpose of connecting the construction land being close to the outer sea with the main road, the old Haishan Road.

\subsection{Route direction}

As to the route direction, the old Haishan Road is not a road extending in a single direction and reaching the end of the road, but inclining to the west after a certain distance. According to judgments, the appearance of this phenomenon is to meet the overall feature of Haishan and the traditional concept of fengshui. Geographically speaking, Haishan where Hongmao Harbour is located, runs from the northwest to the southeast. If the road is parallel to the extension of Haishan, the courtyard houses by the two sides under the land separation would appear to be vertical to Haishan and in southwest-northeast direction. If the courtyard houses face the inner sea, it will be unavoidable to face the so-called "ghost door" (in northeast direction) in fengshui principles. In order to avoid facing the ghost door, the location of a majority of courtyard houses in Hongmao Harbour tended to be in eastern and northeast eastern directions. The selected turning angle is $1 / 24$ of 360 degrees, or called one "mountain head," usually at above 15 degrees. Therefore, the road being parallel to courtyard house forms a deviated angle with the direction of Haishan. If the road goes straight and does not make any turn, it will finally extend to "Neihaizai". In order to avoid this situation, the old Haishan Road was adjusted to make a turn of direction. It 
might be divided into sub-sections which were made to turn slightly to the west when accumulated to a certain volume, or immensely turn to the west at every certain distance. For the way of adjustment to the west to a small extent, a piece of fractional land would be left between the road and courtyard houses, and inclined cutting of land would appear after the westward turning of road. Both impacts would affect the effective use of land. Therefore, with regard to the route planning of Hongmao Harbour, the way of slight westward inclination was carried out by the way of slight adjustment. The westward turning of road appears at the juncture of settlements of different last names, bring least impacts to the use of the land of settlements.

\subsection{Districts}

The districts divided by routes and the eastern and western coasts are mainly the residential units of settlements. The width of each unit block of settlements is about 9.5 to 10 meters, or about 16 to 20 meters. Only a very small part of them appear to be in the dimension of between 5 and 7 meters. The main reasons are the limitation by the width of courthouse and the effective utilization of land. In the early days the folk residence of Hongmao Harbour was primarily the threesided courtyard house in the shape of $\sqcap$. Based on the size, the courtyard houses are mainly of two types: the three-open bayed and five-open bayed ones. The land for the block of a three-open bayed courtyard house is at the width between 9.5 and 10 meters. The land for occupying the block of a five-open bayed courtyard house is at the width between 10 and 20 meters. Besides, there is a majority of the courtyard houses being developed to be long narrow houses, each of which occupies a piece of land at the width between 5 and 7 meters. Later on, with the improvement of the economic situation of the local civilians and the change of construction technology, after the 1950's many courtyard houses were successively demolished. At the original location was built with two pairs of long narrow houses facing each other. From then on, the style and feature of the settlements were changed. Speaking of the depth of the unit block of settlements, before the commencement of the activities of land reclamation and creation of new land, the depth generally ranged from 1.4 to 10.5 meters. The deepest one appeared at the place of cadastral No. 149 153, Haishan $3^{\text {rd }}$ Road. Its depth can accommodate a five-sided courtyard house. Later on, with the development of land reclamation and creation of new land, the unit blocks expanded towards the inner sea, and the depth was thus deepened. As to the western side of Haishan Road, before land reclamation and creation of new land at the inner sea in the early days, there have been many courtyard houses distributed there. But later on, due to the land reclamation and the development of new land, and also the disastrous damage brought to the place whenever great waves came, the civilians gradually migrated to the eastern side of Haishan Road. The flooding of settlements by sea waves frequently occurred until the establishment of embankment in 1953. From then on, the western side of Haishan Road became a piece of stable residential land. Nevertheless, the location of the embankment also limited the depth of its development. The situation sustains until the land reclamation by mechanical power expanded the 
hinterland in the western coast. Then such behaviours as residence and activities crossed over the embankment and expanded towards the west.

\subsection{Nodes}

The major nodes of Hongmao Harbour include temple squares, public squares, ferry pier, and so on. Temple square is a space for the religious worshipping of settlements and the activities of ethnic groups to take place, and is a place with people gathering. The important temple squares of Hongmao Harbour include the squares in front of Feifeng Temple, Feifeng Palace, Chaofeng Temple, Jitian Temple and Chaotian Temple. Among them, the squares in front of Feifeng Palace and Jitian Temple are also used as the markets, so they are the major spots that the daily lives of the people of Hongmao Harbour depend on. The most representative public square is the one in front of Police Bureau. It links with the square in front of Chaofeng Temple. In the early days the pier of the ferries travelling between Kaohsiung City and Cijin was established here. This place has a local name called "Yamen Gate." At its left is built with the office of Haishan United Villages Association.

\section{Structure of ethnic groups, land distribution and development of settlement space}

According to the association with land and the kinship, Hongmao Harbour was also divided into several small settlements. From the south to the north were these settlements: The $1^{\text {st }}$ division was "Putouzai," the $2^{\text {nd }}$ division was "Yang's Family," the $3^{\text {rd }}$ division was "Li's Family," the $4^{\text {th }}$ division was "Hung's Family," and the $5^{\text {th }}$ family was "Su's Family". Except "Putouzai" which was named for its location at graveyard, all other divisions were named by the last name with the majority of population in the area. It reflects the characteristic that Hongmao Harbour was composed of kinship settlements. According to the geographical location and the legends, Yang's residents, Wu's residents and Hung's residents were the first lot of residents settled down in Hongmao Harbour. Later on, there were Li's residents, Su's residents and Chang's residents migrated to this place. Putouzai was formed a little bit later.

Speaking of the various divisions of different last names and the space they owned, the $1^{\text {st }}$ division, "Putouzai" was originally at the edge of the settlements, and close to Linhai aquatic breeding zone. There was the establishment of a graveyard, and the formation of the settlement was a little bit late. The people living there were mainly the residents having the last names of Hong and Yang, as well as a majority of residents with other surnames. It was the division having the most residents of different last names. For the $2^{\text {nd }}$ division of "Yang's Family," a majority of its residents got the last name of "Yang." It was where the Yang's residents of Hongmao Harbour had lived for many generations. The $3^{\text {rd }}$ division of "Li's Family" also included the Wu's and Li's residents, and also very few residents of other last names. Originally this place was resided with Wu's residents for many generations, but during the period of Yongjheng Reign 
(around 1730) a pioneer ancestor with the last name of Li married the daughter of a Wu's resident, and was given the land of Wu's residents. Thus, Wu's residents and Li's residents were found living in the same settlement. Later on, since Wu's residents had less male offspring, part of their land were sold to Hung's residents. Thus, Hung's residents were found to appear between Wu's and Li's residents. The $4^{\text {th }}$ division of "Hung's Family" mainly contained Hung's residents. The $5^{\text {th }}$ division of "Su's Family" was not only resided with Su's residents. At the edge of the settlement were moved in Hung's residents and a majority of other last names. The location of the Second Port was originally resided with Chang's residents for many generations. Due to the opening of the Second Port, the whole village moved from Hongmao Harbour. Currently, the number of last names in Hongmao Harbour has been increased to 46, but Hung, Yang, $\mathrm{Wu}, \mathrm{Li}$ and $\mathrm{Su}$ are still the five great last names in Hongmao Harbour. Their settlements occupy different spaces and each of them has his/her own belief and temple to worship. The families are closely arranged one after another. It is rare to find any large household occupying vast area of land. The residents here have close friendship between neighbours and a strong sense of townsmanship .

Regarding the five major last names, except the ancestral land of Li's residents was acquired through marriage, the ancestral land of the residents of all other last names were inherited from their pioneer ancestors. Later on, as younger generations were multiplied and had their own households, the land was distributed. In the early days, the land area of each household was great, and the population was less. Land was divided into blocks for distribution. With Haishan Road as the boundary line, the land was cut into two blocks in the eastern and the western sides. The criterion of the land size was based on the number of "sweet potato lanes." The land was mostly rectangular or four-sided, and the cutting lines were arrayed parallel in southwest-northeast direction. Although the blocks of land were in different size of area, the basic principle was that the width of a single block of land could accommodate more than one threebay-built or five-bay-built courtyard houses, with the space of passageways preserved. It is observed from this phenomenon that five-bay-built and threebay- built courtyard houses were once the mainstream of the construction of folk residence in Hongmao Harbour. It can also be proved from the interviews and the lines of development of the settlements.

This paper takes the four house-heads of "Li's Family" located on Haishan $3^{\text {rd }}$ Road for example, and elaborates the situation of land distribution in Hongmao Harbour. The four house-heads was inherited by the second generation of the pioneer ancestor, Li Yuan. The land of Li's residents was originally divided into four parts. The $1^{\text {st }}$ house-head was the neighbour of "Wu's Family." Those extending northwards were the $3^{\text {rd }}$ house-head, the $2^{\text {nd }}$ house-head and the $4^{\text {th }}$ house-head. However, with the continuous growth of population, the blocks of land had to face the redistribution of land. According to the number of male offspring, the blocks of land were further sub-divided into smaller blocks of land in long narrow shape. The width of each long narrow land block was equivalent to the width of a three-bay-up courtyard house or a five-bay-up courtyard house. 
Taking the three house-heads of "Li's Family" for example, since there were four sons inheriting the land, the originally distributed land was cut into four long narrow land blocks. But the width of each long narrow land block was too small as too many land blocks were sub-divided, so one long narrow land block could only accommodate a three-bay-built courtyard house. Therefore, only three-bay-built courtyard houses were built at the three house-heads of "Li's Family." This phenomenon was different from the general Hongmao Harbour settlements, which was frequently found to have five-bay-up courtyard houses constructed.

The redistribution of a single long narrow land block was the division of land into front part and rear part, forming two rectangular blocks. The division took the principle that the size of each rectangular block of land could accommodate a three-bay-up courtyard house or a five-bay-up courtyard house, with the space of passageways preserved. If further distribution was required, it would have to break the original layout of a courtyard house. Taking the chamber (commonly called "stretched arm") as the dividing line, the land was divided into left and right portions. The central main hall was dismantled for the use of passageway. (Figure7). Besides, a single long narrow land block could also be distributed into front part, rear part, left part and right part. Similar examples can be found at the courtyard house groups at the $1^{\text {st }}$ house-head of "Wu's Family" at No. 91 93 Haishan $3^{\text {rd }}$ Road (Figure 8).
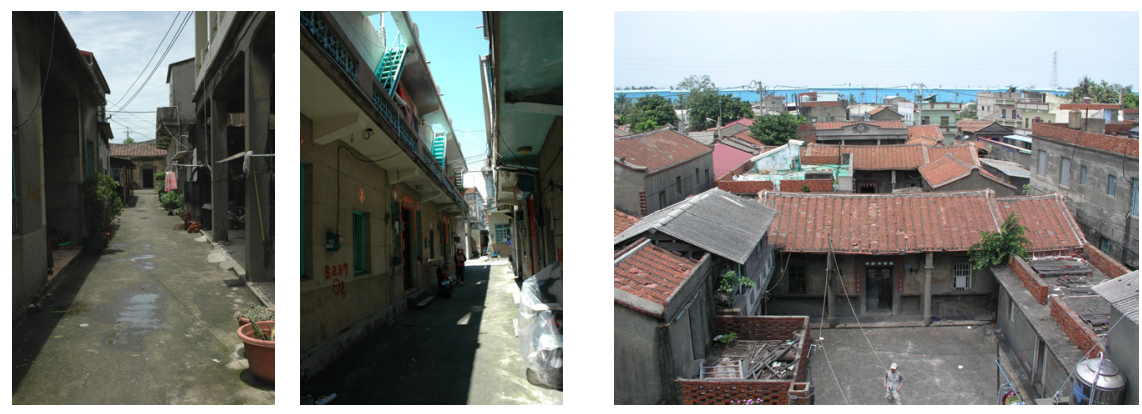

Figure 7: Redistribution of courtyard houses.

Figure 8: House groups at the $1^{\text {st }}$ house-head of "Wu's Family" at No. 91 93 Haishan $3^{\text {rd }}$ Road.

\section{Distribution of ethnic groups and worshipping circles}

According to the formation of human groups of beliefs and the relationship between rights and obligations of each other, the temples of Taiwan are divided into several different types, including corner temple, patriarchal clan temple, crowd temple and entire region temple. Corner temple refers to the temple constructed for the residents of a certain corner. The number of people of a 
corner generally covers the residents of 10 to 100 or 200 households. Their rights and obligations are clearly specified, and the boundary line is also very clear. Patriarchal clan temple is the temple built by the people of a certain last name especially for worshipping gods. The people of the same clan form a worshipping circle. According to the number of sons each household has, they take turns to do the worshipping job. Crowd temple is a worshipping circle taking a dialect or a native hometown as the foundation. It is a temple constructed by the people for their homeland and their gods. Entire region temple is a temple with the belief that all the people of the entire village, town and city worship.

Hongmao Harbour belongs to a coastal settlement. In the settlement, the gods of the main beliefs of different corner temples include Guanyin Buddha, Holy Sacred Mother, Respectful Guangze King, Respectful Baoyi King, Thousandyear-old Hardship Release God for Ho's Family, Land Deity and Holy Granddads, Ancestral Master, concretely reflecting the worshipping of Land Deity and the God of Plagues, as well as the characteristics of the Taiwanese religious beliefs that hold in awe and reverence of lonely souls and wild ghosts.

The form and structure of the worshipping circle of the corner temples in Hongmao Harbour are mainly constructed by five camps. Among the various corner temples, those with more complete information of five camps are Feifeng Temple, Feifeng Palace and Chaofeng Temple. The boundary line of the form and structure of the worshipping circle constructed by these three temples with 5 camps is not only different from today's division of administrative districts, there appears the phenomenon that the corner temples are overlapped with other last names. For example, among the five camps of Feifeng Temple of Putouzai, North Camp never appears in "Wen-antou" that follows "Putouzai" and "Yang's Family." The five camps of Chaofeng Temple do not lie on the border of "Hung's Family," but covering Jitian Temple and Chaotian Temple. This situation explains that the establishment of the five camps for Chaotian Temple in Hongmao Harbour is not only a consideration of spatial area, but also a consideration of other factors. Therefore, the substantive spatial area cannot completely explain the location of the five camps. According to the judgment of the researcher, the distribution and the demarcation of the ethnic groups of the settlements should be another important consideration factor for the establishment of the five camps.

Among the five camps of Feifeng Temple, the location of Central Camp is not far from the original location of Feifeng Temple. South Camp is located at the front end of the settlement of Putouzai. East Camp is at around today's Dalin Thermal Power Plant. West Camp is located by the side of the road of the outer sea at the western end of Putouzai. It is understood that the establishment of these camps is related to the spatial area of settlement. But North Camp is located at the northeastern end on the location opposite to 164-1 Haishan $1^{\text {st }}$ Road. It seems very difficult to understand why the border that signifies the northern end of the worshipping circle is established her, instead of establishing at the place around Wen-antou. In fact if we carefully analyze the last names of the residents living around this place, we can know that the northern part of 
North Camp is mainly the ethnic group of "Yang's Family" who formed a settlement here after migrating to Putouzai. From here, the settlement links to "Yang's Family." And the corner temple of Yang's residents is "Feifeng Palace." Therefore, the North Camp of Feifeng Temple is located at the beginning of the settlement of Yang's residents in Putouzai. The same reason can also explain why the five camps of Chaofeng Temple cover the corner temple of Li's residents, Jitian Temple, as well as the corner temple of Su's residents, Chaotian Temple. The Li's settlement is by the northern side of Haishan Road. At the western margin of the Su's settlement there is the settlement of the ethnic group of Hung's residents. Jitian Temple belongs to the corner temple of Li's residents, whereas Chaotian Temple belongs to the corner temple of Su's residents. In order to protect the Hung's residents of these two places, the five camps of Chaofeng Temple also cover Jitian Temple and Chaotian Temple.

From the above, it is known that the meaning for the establishment of five camps at the corner temples in Hongmao Harbour is to form an area with the relationship of rights and obligations. Each male resident living in this area have to pay money and take part in the activities held by the temples. But the main gods of the temples are responsible for protecting the ethnic groups living within the range of the five camps. This is the meaning of a worshipping circle. Since the settlements by the northern side of Putouzai are mainly created for the kinship of residents, kinship is a major consideration for the construction of the form and structure of the worshipping circle of the corner temples.

\section{Conclusions}

Synthesizing the above, there are five main factors affecting the development and change of the settlements in Hongmao Harbour: the first one is the erosion of sea tide, the second one is the cultural concepts, the third one is the pressure of population growth, the fourth one is the relationship between communities, and the fifth one is the land inheritance system. The erosion of sea tide limited the development at the western side of the settlement. Although there were predecessors living here in the early days, they could not resist the power of the nature and migrated to other places. The words, "construction" on the cadastral maps were changed to be the words, "field," clearly indicating the historical process. Later on, although the predicament was solved by the construction of embankments, the development of settlements was limited. As to the cultural concept, just because of the fengshui concept of having hills behind and sea in front, the residents of Haishan in Hongmao Harbour, with the relief that the western part is elevated and the eastern part is low-lying, mostly chose to build their houses situated in southwestern direction and facing the northeastern direction. The old concepts of "respects for ancestors" and "respects for the central" also made three-sided courtyard houses become the mainstream of folk residence in Hongmao Harbour. In the early $20^{\text {th }}$ century, the settlements of Hongmao Harbour were under the pressure of population growth. Land reclamation and creation of new land by labour were developed continuously. 
Then the settlements extended eastwards, and the topography and morphology were changed accordingly. Later on, under the double effects of the sub-division of land caused by the pressure of population growth and the land inheritance system, as well as the development of construction technology, many courtyard houses were divided into two, forming pairs of one-storey or two-storey long narrow houses. Thus, the arrangement of settlements was completely changed. As to the relationship between ethnic groups, Hongmao Harbour was originally formed by six single-last-name villages. Each single-last-name village lived in different places in Haishan. Later on, due to the factors of population growth, marriage, inheritance of family business by daughters, and migration of population from other places, the relationship between the distribution of ethnic groups of the settlements and space was changed. The population of other places were gradually found living here and there in these six original single-last-name villages. Or the residents of these six single-last-name villages even lived in the places of each other. It was gradually developed that the residents of these six last names were found mutually overlapped in different villages.

In order to meet the shipping needs in the modern times, in 2007 Kaohsiung Harbour has planned to build a new container pier at the place of Hongmao Harbour where the settlements are situated. All the buildings at the settlements of Hongmao Harbour were forced to be completely demolished. The forms and features of these settlements shall not be recovered anymore. Therefore, this paper is written to contribute some efforts to treasuring the valuable old shadows.

\section{Reference}

[1] Chang, Yu-tung, Lin Shih-chao. Foundation Survey, Measurement and Drawing Plan of the Historical Settlements of Hongmao Harbour, Cultural Affairs Bureau of Kaohsiung City Government, Kaohsiung, 2006. 